and Bass and Wade in their study of patients referred for coronary artery angiography found higher type A scores among those with normal coronary arteries. ${ }^{6}$ Although type A people may not admit to cardiovascular symptoms under some circumstances, ${ }^{26}$ one who presents in casualty might insist on being thoroughly investigated. Similarly, type A people seem to experience more stressful life events than type B people, particularly related to work, ${ }^{27}$ although it might be that type A people report more work associated events than their type B colleagues.

Clearly the type A behaviour pattern is complex, as is its association with coronary heart disease, and we need to recognise shortcomings in the studies done so far. Even if well designed studies show a significant association between the type A behaviour pattern and coronary heart disease they will not prove causation. The best evidence would come from intervention studies, and Friedman and colleagues have reported that reducing type $A$ behaviour by counselling after myocardial infarction leads to a dramatic and sustained drop in subsequent cardiac morbidity. ${ }^{428}$ This kind of result surely justifies further investigation of the type A behaviour pattern rather than its dismissal for its inconsistent track record.

Lecturer in Psychiatry,

TOM SENSKY

Charing Cross and Westminster Medical School,

London W6 8RF

1 Friedman M, Rosenman RH. Association of specific overt behaviour pattern with blood and cardiovascular findings. JAMA 1959;169:1286-96.

2 Friedman M, Rosenman RH. Type A behaviour and your heart. London: Wildwood House, 1974.

3 Rosenman RH. The interview method of assessment of coronary-prone behaviour. In: Dembroski TM, Weiss SM, Shields JL, Haynes SG, Feinleib M, eds. Coronary-prone behaviour. New York: Springer, 1978:55-69.

4 Friedman M, Thoresen CE, Gill JJ, et al. Alteration of Type A behaviour and its effect on cardiac recurrences in post-myocardial infarct patients: summary results of the Recurrent Coronary Prevention Project. Am Heart $\mathcal{f}$ 1986;112:653-65.

5 Dimsdale JE, Hackett TE, Block PC, Hutter AM. Emotional correlates of Type A behaviour pattern. Psychosom Med 1978;40:580-3.

6 Bass C, Wade C. Type A behaviour: not specifically pathogenic? Lancet 1982;ii:1147-50.

7 Frank KA, Heller SS, Kornfield DS. Type A behaviour pattern and coronary angiographic Frank KA, Heller SS, Kornfield DS.
findings. JAMA 1978;240:761-3.

8 Pickering TG. Should studies of patients undergoing coronary angiography be used to evaluate the role of behavioural risk factors for coronary heart disease? F Behav Med 1985;8:203-13.

9 Rosenman RH, Brand RJ, Jenkins CD, et al. Coronary heart disease in the Western Collaborative Group study: final follow-up experience of 8.5 years. FAMA 1975;233:872-7.

10 Haynes SG, Feinleib M, Kannel WB. The relationship of psychosocial factors to coronary heart disease in the Framingham study. Am $\mathcal{F}$ Epidemiol 1980;111:37-58.

11 Shekelle RB, Hulley SB, Neaton JD, et al. The MRFIT behaviour pattern study. II. Type A behaviour and incidence of coronary heart disease. Am $\mathcal{F}$ Epidemiol 1985;122:559-70.

12 Waldron I. Sex differences in the coronary-prone behaviour pattern. In: Dembroski TM, Weiss SM, Shields JL, Haynes SG, Feinleib M, eds. Coronary-prone behaviour, New York: Springer, 1978:199-205.

13 Zyzanski SJ, Wrzesniewski $\mathrm{K}$, Jenkins $\mathrm{CD}$. Cross-cultural validation of the coronary-prone behaviour pattern. Soc Sci Med 1979;13A:405-12.

14 French-Belgian Collaborative Group. Ischaemic heart disease and psychological patterns: French-Belgian Collaborative Group. Ischaemic heart disease and psychological
prevalence and incidence studies in Belgium and France. Adv Cardiol 1982;29:25-31.

15 Gallacher JEJ, Yarnell JWG, Elwood PC, Phillips KM. Type A behaviour and heart disease Gallacher JEJ, Yarnell JWG, Elwood PC, Phillips KM. Type A be
prevalent in men in the Caerphilly study. BrMed $\mathcal{1}$ 1984;289:732-3.

16 Cohen JB, Reed D. The Type A behaviour pattern and coronary heart disease among Japanese men in Hawaii. $\mathcal{J}$ Behav Med 1985;8:343-52.

17 Stockwell N, Zyzanski SJ, Yodfat Y. Type A behaviour in two ethnic rural communities of males in Israel with and without coronary heart disease. Soc Sci Med 1985;20:331-4.

18 Byrne DG, Rosenman RH, Schiller E, Chesney MA. Consistency and variation among instruments purporting to measure the Type A behaviour pattern. Psychosom Med 1985;47: 242-61.

19 Langeluddecke PM, Tennant CC. Psychological correlates of the Type A behaviour pattern in coronary angiography patients. Brf Med Psychol 1986;59:141-8.

20 Jenkins CD, Zyzanski SJ, Rosenman RH. Coronary prone behaviour: one pattern or several? Psychosom Med 1978;40:25-43.

21 Jenkins CD, Rosenman RH, Zyzanski SJ. Prediction of clinical coronary heart disease by a test for the coronary-prone behaviour pattern. N Engl I Med 1974;290:1271-5.
the

22 Bortner RW. A short rating scale as a potential measure of Pattern A behaviour. $\mathcal{f}$ Chronic Dis 1969;22:87-91.

23 Haynes SG, Levine S, Scotch N, et al. The relationship of psychosocial factors to coronary heart disease in the Framingham study: I. Methods and risk factors. Am $\mathcal{F}$ Epidemiol 1978;107: 362-83.

24 Case RB, Heller SS, Case NB, et al. Type A behaviour and survival after acute myocardial infarction. N Engl f Med 1985;312:737-41.

25 Ahnve S, de Faire U, Orth-Gomer K, Theorell T. Type A behaviour in patients with non-coronary chest pain admitted to a coronary care unit. F Psychosom Res 1979;23:219-23.

26 Swan GE, Chesney MA, Black GW, Ward MM, Rosenman RH. Self-reported somatic symptoms in Type A and Type B middle-aged males. Stress Medicine 1986;2:63-8.

27 Byrne DG, Rosenman RH. The Type A behaviour pattern as a precursor to stressful life-events: a confluence of coronary risks. Brf Med Psychol 1986;59:75-82.

28 Friedman $M$, Thoresen CE, Gill JJ, et al. Alternation in Type A behaviour and reduction in cardiac recurrences in postmyocardial infarction patients. Am Heart $\mathcal{1}$ 1984;108:237-48.

\section{Renal micropolyarteritis}

The kidneys are commonly affected in polyarteritis, and several recent reports suggest that they are most often affected when the inflammation damages mainly the smaller arteries and the vessels distal to them. ${ }^{1-4}$ This renal disease is now often called micropolyarteritis, though the systemic manifestations are still described as angiitis or vasculitis; the term allergic, hypersensitivity, malignant, or necrotising is sometimes added to draw attention to other important aspects of the condition.

Because the vascular lesions are not confined to the kidney patients are often referred initially to general physicians, dermatologists, or rheumatologists. Gastroenterologists may see patients with disease of the gut, liver, or spleen, and the eyes are often affected. Wegener's granulomatosis, which is a closely associated condition, may present to the ear, nose, and throat or chest department. Infection will often be suspected because of a flu like prodromal illness or because of the fever and malaise that usually accompany renal micropolyarteritis.

The kidneys may be affected early or late in the disease, and any doctor managing a case of proved or suspected angiitis must regularly check the plasma creatinine concentration and examine the urine for red cells and casts. A nephrologist should be called immediately renal damage is suspected as it may progress rapidly to advanced renal failure, which not only reduces the chance of retrieving renal function but also increases the hazards of immunosuppressive treatment.

In a patient with renal micropolyarteritis the doctor is more likely to make the diagnosis by biopsy of the kidney rather than of more accessible tissues, and renal biopsy has been shown to be safe. The histological appearances have been well described, ${ }^{5}$ but the typical foci of vascular and glomerular necrosis may be absent and the diagnosis may then still rest on extrarenal evidence. Seldom is there evidence of immune complex deposition, although tests for circulating complexes are often positive. ${ }^{346}$ In a patient with a lung haemorrhage or purpuric rash immunohistological investigation may, nevertheless, be helpful since it will show the absence of the linear immunoglobulin pattern of Goodpasture's syndrome and the IgA deposits typical of Henoch-Schönlein syndrome.

Though spontaneous remission has been reported, immunosuppressive treatment should not be delayed if the patient has haematuria, uraemia, or a raised erythrocyte sedimentation rate. Many treatment regimens have been tried, but the yardstick against which they must be measured is the prednisolone-cyclophosphamide combination described by Fauci's group. ${ }^{78}$ They give excellent advice about adjusting doses to fit the severity of the disease, both initially and during follow up. ${ }^{78}$ Their results in Wegener's granuloma and vasculitis affecting the kidney are far better than those in earlier reports.

The recent studies from London and Sheffield confirm that the prognosis in renal micropolyarteritis is more favourable than was believed and better than in classic polyarteritis nodosa. ${ }^{13}$ Most patients now survive the first few months with useful renal function, and they then have an excellent chance of avoiding long term haemodialysis. Even patients requiring dialysis sometimes improve enough for it to be stopped.

The most recent development is that workers in Holland 
and London ${ }^{10}$ have shown that antibodies to neutrophil cytoplasmic antigens can be detected and measured in the plasma of patients with Wegener's granuloma and vasculitis. This holds out the promise of a test that will help both in diagnosing the condition and in monitoring its activity.

A Polak

Consultant Nephrologist

Wessex Regional Renal Unit,

St Mary's Hospital,

Portsmouth PO3 6AD

i Coward RA, Hamdy NAT, Shortland JS, Brown CB. Renal micropolyarteritis; a treatable condition. Nephrology Dialysis Transplantation 1986;1:31-37.

2 Balow JE. Renal vasculitis. Kidney Int 1985;27:954-64.

3 Serra A, Cameron JS, Turner DR, et al. Vasculitis affecting the kidney. Presentation, histopathology and longterm outcome. Of Med 1984;210:181-207.

Pinching AJ, Lockwood CM, Pussell BA, et al. Wegener's granulomatosis; observations on 18 patients with severe renal disease. $\mathcal{f}$ Med 1983;208:435-60.

patients with severe renal disease. I Med 1983;208:435-60.

5 MacIver AG, Darmady EM. Renal histology. London: Butterworths, 1980:316-7.

Droz D, Noel $\mathrm{H}$, Leibowitch M, Barbanel C. Glomerulonephritis and necrotising angiitis. Adv Nephrol 1979;8:343-6.

7 Fauci AS, Katz.P, Haynes BF, Wolff SM. Cyclophosphamide therapy for severe necrotising vasculitis. N Engl f Med 1979;301:235-8.

8 Fauci AS, Haynes BF, Katz P, Wolff SM. Wegener's granulomatosis: prospective clinical and therapeutic experience with 85 patients for 21 years. Ann Intern Med 1983;98:76-85.

9 Van Der Woude FJ, Rasmussen N, Lobatto S, et al. Auto-antibodies against neutrophils and monocytes: tool for diagnosis and marker of disease activity in Wegener's granulomatosis. Lancet 1985; i:425-9.

10 Lockwood CM, Bakes D, Jones S, Whitaker KB, Moss DW, Savage COS. Association of alkaline phosphatase with an autoantigen recognised by circulating anti-neutrophil antibodies in systemic vasculitis. Lancet 1987; ;:716-9.

\section{Resuscitating resuscitation}

Sudden death is always disturbing, especially when it occurs in the young. Even more distressing is when the death could have been avoided given certain elementary skills in those present at the scene of the catastrophe. In hospitals such skills are taken for granted, but they are not always available, says a report published last week by the Royal College of Physicians. ' Junior hospital doctors and nurses in many hospitals are not familiar with basic life support techniques, and few hospitals instruct their doctors and nurses in resuscitation. Regular revision classes are certainly not held, according to the report.

The committee preparing the report drew these inferences from published work rather than from any qualitative investigation of its own. If the allegations are correct then the failure must be remedied rapidly as there can be no excuse for doctors being unable to respond quickly, effectively, and humanely in an emergency. The report gives clear guidelines for training and for the organisation of resuscitation services in hospitals, the community, and in specialised areas. Its recommendations on the training of medical students, young doctors, and nurses in life support methods should be adopted as obligatory elements of their training. All National Health Service staff in regular contact with patients should receive instruction in basic life support techniques using training mannikins, and they should attend regular refresher courses.

Every hospital should have an on call resuscitation team skilled in all the disciplines of advanced life support; this team will have to integrate with those on site who start first aid. The resuscitation team must have a designated leader to take complete responsibility to avoid confusion-and therein lies the basic problem. In Britain crash teams consist most often of junior doctors of equal rank, and it is unusual to have a member who is sufficiently senior to take charge and carry the responsibility.

The recommendation that each hospital should have a formally constituted resuscitation committee is an important idea that should allow the introduction of audit and the establishment of clear operational guidelines. The appointment of district resuscitation training officers would go some way to ensuring the provision of continuing education and the maintenance of standards, which the report recognises as important. The officers' duties would include not only organising basic training and refresher courses for hospital staff but also training staff in health centres, dental surgeries; factories, schools, large shops, and offices in basic resuscitation techniques. Training ambulancemen along the lines of North American paramedics and paying them for the skills they achieve would be welcomed both by the ambulance service and by the general public. The ambulance makes an ideal resuscitation vehicle, and it should be equipped with "intelligent" defibrillators.

The college committee is to be congratulated on producing such a succinct report. But I regret that no anaesthetist was included since anaesthetists have so often taken the lead in developing resuscitation and intensive care services. It is also a pity that more space was not devoted to the ethics of resuscitation for while it is bad practice to fail to resuscitate it is equally bad to treat aggressively those who should be allowed to die peacefully. For many doctors this is the most difficult assessment to make.

Reader in Surgery and Consultant Surgeon,

R W G JoHNSON

Manchester Royal Infirmary,

Manchester M13 9WL

1 Royal College of Physicians. Resuscitation from cardiopulmonary arrest. Training and organisation. London: RCP, 1987

\section{Coventry: a no drinking-driving city by the year 2000 ?}

Coventry City Council, Coventry Health Authority, and Coventry and Warwickshire Alcohol Advisory Service are planning to make Coventry a no drinking and driving city by the year 2000. In 1985, 25 people died on the roads in Coventry, and eight of these deaths could be attributed to alcohol. In the same year we estimate that 140 injuries on the road were related to alcohol. National action will, we believe, be necessary to reduce alcohol associated injuries on the roads, but local action will also be important.

In the autumn of last year we brought together the organisations in Coventry who will have a part to play in making Coventry a no drinking and driving city. We included those with vested interests in transport and alcohol. The recommendations of the seminar have been endorsed by the city council's public works and consumer protection committee. Dr James Dunbar of the Tayside Safe Driving Project told the seminar about his project and about the Finnish experience of how random breath testing and reducing the blood alcohol concentration above which driving is illegal to $50 \mathrm{mg} / 100 \mathrm{ml}$ led to a fall in road traffic accidents (p 101). The meeting supported the idea of a lower limit and random breath testing for Britain. It also wanted to see more 